\title{
PENGGUNAAN RUANG PUBLIK SEBAGAI TEMPAT BERJUALAN PEDAGANG KAKI LIMA DI KOTA SORONG
}

\author{
(Studi Pada Area Toko Thio di Kelurahan Remu Utara)
}

\author{
Uswatul Mardliyah ${ }^{1}$, Nanik Purwanti ${ }^{2}$, Firda Yoan Sarapayari ${ }^{3}$ \\ ${ }^{1}$ Program Studi Sosiologi, FISIP, Universitas Muahmmsdiyah Sorong, Indonesia \\ ${ }^{2}$ Program Studi Sosiologi, FISIP, Universitas Muahmmsdiyah Sorong, Indonesia \\ ${ }^{3}$ Program Studi Sosiologi, FISIP, Universitas Muahmmsdiyah Sorong, Indonesia
}

*Korespondensi: uswatul.mardliyah@gmail.com

\section{ABSTRACT}

This study tries to describe and analyze the use of public space as a place to sell street vendors in Sorong City (Study in the Thio Shop Area, North Remu Village). The activities of street vendors are a phenomenon of small people's economic activities, where they trade to meet their daily needs. The data collection technique used in the research is by means of field research which consists of observation, interviews, and documentation. The result of this research is the use of public space as a place to sell street vendors. Where the street vendors get a location in a public space with the help of one of the street vendors at that location or in other words through an intermediary, to make the process of occupying a trading location easier. Street vendors also previously reported to the shop owner and to the person who has authority at the location and agreed to the rules that were agreed orally, so that they could occupy trading locations around the shop. Traders who are in this location are one of the crowded places that are used by traders to sell because the value of economic turnover in urban areas is quite large and greatly affects the income of street vendors in Sorong City.

Keywords: Use of Public Space, Street Vendors

\begin{abstract}
ABSTRAK
Penelitian ini mencoba untuk mendeskripsikan dan menganalisis tentang Penggunaan Ruang Publik Sebagai Tempat Berjualan Pedagang Kaki Lima di Kota Sorong (Studi Pada Area Toko Thio Kelurahan Remu Utara). Kegiatan Pedagang Kaki Lima merupakan fenomena kegiatan perekonomian rakyat kecil, dimana mereka berdagang untuk memenuhi kebutuhan sehari-hari mereka. Teknik pengumpulan data yang digunakan dalam penelitian adalah dengan cara penelitian lapangan yang terdiri dari observasi, wawancara, dan dokumentasi. Hasil penelitian ini adalah Penggunaan Ruang Publik Sebagai Tempat Berjualan Pedagang Kaki Lima. Dimana Para pedagang kaki lima memperoleh lokasi di ruang publik dengan bantuan dari salah satu pedagang kaki lima dilokasi tersebut atau dengan kata lain melalui perantara, untuk lebih mudah dalam proses menempati lokasi berdagang. Pedagang Kaki Lima juga sebelumnya sudah melapor kepada pemilik toko dan kepada orang yang memiliki wewenang di lokasi tersebut dan menyanggupi aturan-aturan yang disepakati secara lisan, sehingga dapat menempati lokasi berdagang di sekitar toko. Pedagang yang berada di lokasi tersebut merupakan salah satu tempat keramaian yang dimanfaatkan para pedagang untuk berjualan karena nilai perputaran ekonomi di perkotaan yang cukup besar dan sangat mempengaruhi pendapatan para pedagang kaki lima di Kota Sorong.
\end{abstract}

Kata kunci: Penggunaan Ruang Publik, Pedagang Kaki Lima 


\section{PENDAHULUAN}

Setelah bergejolaknya krisis ekonomi dunia pada tahun 1998, perekonomian Indonesia lebih cenderung beralih pada sektor informal yaitu Pedagang Kaki Lima. Jatuhnya perekonomian Indonesia sangat berpengaruh terhadap kehidupan masyarakat terutama kelas menengah ke bawah serta menambah jumlah pengangguran di dalam negeri. Sethuraman, S. V. (1991) Semenjak krisis ekonomi tersebut terjadi, maka lahirlah sektor informal. Dalam sektor informal ini selain sebagai penyedia lapangan kerja, serta tentunya juga menambah suasana yang berbeda. Karena dalam sektor ini yang sangat menonjol dilihat dari aktifitasnya adalah Pedagang Kaki Lima (PKL).

Pedagang Kaki Lima adalah orangorang yang menjajakan barang dagangan di pinggir-pinggir jalan atau menggunakan ruang publik. Menurut Arditama (2016:70) ruang publik merupakan tempat bertemunya multi aktor yang memiliki berbagai kepentingan. Salah satu bentuk aktor adalah pedagang yang menggunakan ruang publik sebagai sektor ekonomi informal masyarakat perkotaan.

Dengan menggunakan ruang publik sebagai tempat berdagang, Pedagang Kaki
ISSN 2614-4336

VDL. 7 No.I HAL. 44-53

Lima telah mencederai aktivitas masyarakat lain sebagai pengguna jalan. Hal ini disebebkan lapak jualan berupa tenda, gerobak dan lain digunakan sebagai tempat memasarkan barang daganganya, salah satunya di sekitar TokoThio Kelurahan Remu Utara.

Di sekitaran Toko Thio Kelurahan Remu Utarayang banyak dikunjungi oleh masyaraka, khususnya yang ada di Kota Sorong, para Pedagang Kaki Limayang berjualan di kawasan toko ini merupakan bagian dari masyarakat yang berusaha mencari uang dengan cara menjual dagangan merekauntuk pemenuhan kebutuhan sebagian anggota masyarakat. Mengingat semakin banyak jumlah pedagang kaki lima yang muncul di area pertokoan ini, tentu semakin memperkecil dan mempersempit area parkir dan penggunaan jalan disekitar pertokoan.

Hal ini meresahkan dan sangat menganggu pemilik pertokoan dan juga warga masyarakat pengguna jalan karena ruang gerak mereka menjadi terbatas. Penggunaan ruang telah dikelompokkan berdasarkan struktur dan fungsi ruang.Struktur dan fungsi ruang tersebut seharusnya dapat dijadikan dasar atau acuan dalam menggunakan ruang publik. 
Menurut Pasal 19 Undang-Undang Nomor 26 Tahun 2007 tentang Penataan Ruang, ditegaskan bahwa struktur ruang memuat susunan pusat-pusat permukiman. Serta diperkuaat dengan Peraturan Daerah Kota Sorong Nomor 36 Tahun 2013 Tentang Penataan dan Pembinaan Pedagang Kaki Lima. Toko berada di wilayah/ kawasan Kota Sorong, ini merupakan salah satu pusat kegiatan perekonomian kota pada waktu siang maupun malam hari.

Kegiatan ini juga sudah berlangsung cukup lama, mengingat area pertokoan yang ramai sehingga menarik warga atau masyarakat baik untuk berdagang ataupun berbelanja. Hal ini yang menarik pedagang untuk menjajakan dagangannya dan hingga kini berkembang pesat sebagai lokasi kegiatan Pedagang Kaki Lima yang berdagang pada sore hingga malam hari yang sudah sangat dikenal juga sebagai salah satu lokasi wisata kuliner bagi masyarakat Kota Sorong.

Pedagang kaki lima yang menggunakan ruang publik adalah salah satu fenomena kegiatan perekonomian yang dilakukan sebagian masyarakat ekonomi menengah bawah. Ini dilakukan untuk menyambung hidup dan memenuhi kebutuhan pokok mereka sehari-hari.
Munculnya para pedagang kaki lima ini, sudah tentu erat kaitannya dengan kondisi perekonomian saat ini, dikarenakan sulitnya lapangan pekerjaan yang didapatkan oleh masyarakat dalam kondisi keterampilan individu yang terbatas dalam mengakses perkembangan teknologi terhadap barang yang dipromosikan.

Usaha yang dapat dilakukan dengan keterampilan yang dimiliki dalam bidang kuliner, menjajakan topi, tas, boneka, pinang, buah, VCD dan lain sebagainya memberikan peluang usaha menghasilkan uang guna pemenuhan kebutuhan hidup. Pedagang Kaki Lima ini juga muncul karena kurangnya lapangan pekerjaan untuk rakyat kecil yang tidak memiliki kemampuan dalam berproduksi.

Berdasarkan uraian diatas, penulis tertarik untuk meneliti tentang Penggunaan Ruang Publik Sebagai Tempat Berjualan Pedagang Kaki Lima di Kota Sorong (Studi Pada Area Toko Thio Kelurahan Remu Utara).

\section{METODE}

Metode penelitian yang digunakan dalam penelitian ini adalah metode kualitatif. Menurut Creswell (2016) penelitian kualitatif adalah jenis penelitian yang mengeksplorasi dan memahami 
makna dari sejumlah individu atau sekelompok orang yang berasal dari masalah sosial, yang dipahami sebagai prosedur riset yang memanfaatkan data deskriptif, berupa kata-katadan ucapan dari orang yang diamati.

Pengumpulan data dilakukan melalui Observasi, wawancara dan dokumentasi. Dalam hal di mana data deperoleh dan dikembangkan dengan menyusun, menjelaskan, menguraikan dan menganalisis berdasarkan rumusan masalah dan tujuan dari penelitian yaitu Penggunaan Ruang Publik Sebagai Tempat Berjualan Pedagang Kaki Lima Di Kota Sorong (Studi Pada Sekitaran Toko Thio Di Kelurahan Remu Utara).

\section{HASIL DAN PEMBAHASAN}

\section{Penggunaan Ruang Publik Sebagai} Tempat Berjualan Pedagang Kaki Lima

Seiring dengan lajunya pertumbuhan ekonomi yang merupakan wajahnya di kota-kota besar, faktor migranpun semakin bervariasi. Berbagai faktor sosial, ekonomi maupun psikologi sangat mempengaruhi keputusan calon migrant untuk melakukan migrasi. Masyarakat desa kini lebih bersifat proaktif dalam meraih kesempatan dan kemakmuran yang mereka inginkan di kota. Pedagang Kaki Lima tumbuh dan mengalami perkembangan yang pesat di kota karena peningkatan pertumbuhan keadaan masyarakat yang kondusif, berakibat pada eksistensi kegiatan Pedagang Kaki Lima memerlukan alokasi tempat yang permanen. Berkembang Pedagang Kaki Lima di ruang perkotaan akibat kondisi sosial ekonomi di perkotaan, dan kesejarahan aktivitasnya, sehingga keberadaan aktivitas Pedagang Kaki Lima di ruang perkotaan menjadi aktivitas yang perlu diakomodasi oleh pihak-pihak yang memiliki kewenangan terhadap hidup dan kesejahteraan masyarakat.

Kewenangan dan kesejahteraan masyarakat Kota Sorong yang peneliti diwawancarai Kepala Kelurahan Remu berinisial F.B (48 Tahun) memaparkan bahwa:

Penggunaan ruang publik yang digunakan sebagai tempat berjualan pedagang kaki lima sering mendapat stigma negative tentang keberadaan mereka, dan semakin kental stigma tersebut ketika muncul wacana keindahan kota, jika dilihat dari segi estetika lingkungan, maka keberadaan PKL menimbulkan kesan kumuh dan sembrawut. Namun dengan adanya keberadaan PKL, kita justru di untungkan dengan diberi pelayanan yang mudah dan cepat untuk mendapatkan barang yang kita butuhkan. (Wawancara November 2020) 
Penggunaan ruang publik yang digunakan para PKL kebanyakan adalah orang-orang yang kurang tinggi pendidikannya, namun ada beberapa pedagang yg berpendidikan tinggi namun memilih terjun pada sektor informal ini karena kurangnya lowongan pekerjaan.

Dapat kita ketahui bahwa Penggunaan Ruang Publik sangatlah berpengaruh terhadap pendapatan perekonomian masyarakat yang menggunakan ruang publik sebagai lahan untuk berdagang. Sebagaimana salah seorang peneliti temukanyang berinisial Ibu L (45 Tahun) selaku Pedagang Kaki Lima (PKL) yang berjulan Gorengan mengatakan bahwa:

Berjualan di sekitar toko thio sangatlah strategis bagi kami para pedagang kaki lima. Saya berjualan gorengan di soreh hari di sekitar toko thio merasakan sendiri betapa straegisnya lokasi saya karena gorengan saya sering sekali terjual habis di borong para pengendara yang hendak pulang beraktifitas atau pun yang sembari berhenti menunggu lampu hijau dan ada juga yang pembeli para muda-mudi yang membeli gorengan saya untuk di bawah ke tempat taman kota untuk menikmati suasana sore hari di Kota Sorong. (Wawancara November 2020)

Jika dilihat secara umum semua kota-kota besar yang ada di Indonesia, sama halnya yang terlihat di Kota Sorong Papua Barat, ruang publik sering digunakan sebagai tempat yang strategis bagi pedagang dalam menjajakan barang dagangnya. Hal ini dapat dilahat dari karakteristik pembeli itu sendiri. Dimana pembeli biasaya menempatkan diri apabila barang belanjaan mudah didapatkan, tidak perlu waktu lama untuk mendaptkanya, yang pada akhirnya membuat masyarakat atau pembeli merasa malas untuk masuk ke pasar sentral yang secara kebutuhan terpenuhi.

Dalam hal ini khususnya, pertumbuhan dan perkembangan Pedagang Kaki Lima yang berlokasi di ruang terbuka (square) dan ruang sirkulasi (street) di perkotaan telah mengubah fungsi ruangruang tersebut, sehingga tidak sesuai lagi dengan peruntuhkanya bagi masyarakat, serta menurunkan kualitas lingkungan sebagai tempat yang kumuh dan tidak tertata dengan baik.

\section{Pedagang Kaki Lima sebagai} aktivitas sektor informal dalam kegiatan perdagangan dan jasa di ruang kota, beraktivitas di ruang-ruang publik kota. Kondisi ini lambat laun menimbulkan adanya kesenjangan antara pasaran kerja dengan pertumbuhan pencari kerja. Kenyataan tersebut umumnya hampir 
ISSN 2614-4336

VDL. 7 No.I HAL. 44-53

terjadi pada setiap masyarakat baik kelas menengah kebawah sebaliknya serta di perkotaan ataupun pedesaan.

Munculnya pedagang kaki lima di sektor publik memudahkan masyarakat dengan memberi pelayanan yang tepat dan cepat terhadap kebutuhan brang yang akan dibelih. Selain itu, Pedagang Kaki Limi juga menciptakan peluang kerja, apalagi dalam situasi dan kondisi saat ini yang terjadi di masyarakat betapa susahnya mendaptkan lapangan pekerjaan serta bertambahnya angka pengguran akibat dari ketidakberdayaan masyarakat menghadapi krisis itu sendiri.

\section{Sebagai masyarakat menyadari} bahwa tingkat pengangguran sangatlah tinggi dan dari banyaknya pengangguran disitu lahirlah sektor informal dimana para pencari kerja melihat adanya peluang untuk berdagang dengan cara mendirikan pasar, menggunakan ruang publik sebagai landasan utama. Ruswinarsih, M. F. S., \& Nur，R. (2021) secara tidak langsung dengan adanya pasar tersebut terjadilah aktivitas perdagangan yang mempertemukan penjual dan pembeli. Yang pada akhirnya meningkatkan perekonomian masyarakat dengan terbentuklah Pedagang Kaki Lima itu sendiri.

\section{Kendala dalam Menggunakan Ruang Publik Sebagai Tempat Berjualan di Kelurahan Remu Utara Kota Sorong}

Sering kita dengar dan jumpai penertiban yang dilakukan Pemerintah Kota terhadap Pedagang Kaki Lima yang keberadaannya di pusat-pusat keramaian di Kota Sorong yang dijalankan oleh Sat Pol PP dinama sebagai penegak aturan ketertiban dibawah Pemerintah Kota Sorong (Rusdi, R. dkk. 2021). Salah satunya di sekitar area Toko Thio yang menjadi penertiban dengan menata agar keamanan dan kenyamanan dapat berjalan dengan baik. Pada saat sudah menjelang sore dan malam lokasi tersebut sangat ramai di kunjungi oleh para pembeli. Namun dalam pemanfaatan dan penggunaan ruang publik, para pedagang kadangkala mendapat berbagai macam masalah di lokasi tempat mereka berdagang. Dalam hal ini untuk mengetahui masalah yang dialami oleh para Pedagang Kaki Lima dalam penggunaan ruang publik sebagai tempat berjualan di sekitar Toko Thio Kelurahan Remu Utara Kota Sorong.

Pedagang Kaki Lima dan pembeli/pengunjung yang menggunakan ruang publik sebagai tempat aktivitas berjualan dan tempat perbelanjaan para 
pembeli, sering mendapatkan masalah atau ancaman yang terjadi di tempat dagangan, kendala yang sering kali dirasakan para PKL sebagaimana yang diutarakan oleh salah seorang pedagang berinisial Bpk H.R (40 tahun) penjual nasi kuning sebagai berikut:

Adanya pungutan liar yang dari oknum-oknum yang tidak dikenal serta tidak memiliki wewenang dalam kesepakatan izin untuk membuka stan semi permanen yang kita lakukan untuk menunjang penjualan kami. (wawancara November 2020)

Kendala lain juga ditemukan oleh para pedagang, dengan adanya kehadiran orang mabuk dan pada demonstrasi terjadi yang kadang berunjuk perkelahian atau ricuh sehingga membuat para pedagang kaki lima merasa terganggu atau bahkan merasa terancam atas keselamatan mereka maupun barang atau lapak dagangan. Hal ini dibenarkan oleh seorang ibu berinisial Y. K (38 tahun) penjual pinang Menggambarkan sebagai berikut:

Pada saat anak-anak demontrasi kami pedagang merasa tidak nyaman, misalnya saja kemarin demo tentang Otsus yang berakibat ricuh sehingga kami pedagang ikut terancam dimana para demontan berhamburan lari dan bersembunyi dilapak jualan kami. (wawancara November 2020)
Yang pada akhirnya pedagang merasa rugi atau minimnya para pembeli yang berdampak pada pendapatan penjualan. Adapun kendala lain yang di rasakan oleh pedagang kaki lima adalah menurunnya penghasilan para pedagang akibat dari dampak dari Covit-19 yang membuat sepi pengunjung karenan takut oleh penyebaran virus.

Selainm itu, adanya rasa perlawanan terhadap covid-19 dalam pemenuhan kebutuhan masyarakat, terutama kebutuhan sehari-hari yang berdampak pada perlawanan yang dilakukan individuindividu dan kelompok dalam proses sosial di antara sesama pedagang serta masyarakat lain sebagai pengguna ruang publik. Slamet Santoso (2004) Persaingan merupakan proses sosial, yakni kelompok dan orang perorang yang bekerja keras serta bersaing untuk memperoleh keuntungan dan menghasilkan uang dengan cara menarik perhatian masyarakat yang sedang berkunjung ke ruang-ruang publik yang dijadikan tempat para pedagang kaki lima menjajakan dagangannya.

Dalam persaingan ini tentu banyak cara yang dilakukan oleh pedagang agar dagangannya menjadi laku atau terjual, tentunya tiap pedagang punya triknya 
masing-masing yang ditonjolkan, namun perlu untuk dihindari adalah memunculkan prasangka agar tidak terjadipertikaian atau konflik. Ritzer George \&Goodman J Douglas (2017) Persaingan dan konflik merupakan bagian dari dinamika masyarakat yang tidak dapat dihindarkan.

Hal ini karena latar belakang budaya, dan perilaku yang berbeda, namun kesadaran individu bisa menjadi kontrol penting guna menciptakan persaingan yang sehat. Sehingga tercipta suasana yang lebih terbuka bagi para pedagang. Perbedaan tersebut menjadi suatu pertikaian dimana pertikaian akan mengakibatkan ketidaknyamanan baik secara fisik dan mental.

Pedagang Kaki Lima atau (PKL) dan pengunjung atau pembeli yang menggunakan ruang publik juga memiliki sifat atau tindakan dalam menggunakan ruang publik sebagai proses interaksi sosial yang positif antara perorangan (penjual) dan atau kelompok masyarakat (pembeli) yang menghasilkan hubungan kerja sama yang baik untuk mencapai tujuan bersamasama.

Bentuk kerjasama bisaberhubungan antara pembeli atau pengunjung dengan Pedagang Kaki Lima dengan menggunkan ruang publik sebagai salah satu wujud proses interkasi sosial yang bersifat terbuka. Proses dalam memasarkan barang daganganya oleh pedagang serta sifat penawaran terhadap barang dan jasa tersebut.

\section{Pemenuhan kebutuhandigunakan} dalam dua makna, pertama adalah proses yang menunjukan pada keadaan seimbang dalam interaksi sosial antara individu dan antar kelompok dalam masyarakat terutama yang ada hubungannya dengan norma dan nilai sosial para pedagang yang berlaku dalam lingkungan masyarakat tersebut. Hubungan antara pembeli dengan Pedagang Kaki Lima menciptakan kestabilan dalam masyarakat di bidang ekonomi.

\section{SIMPULAN}

Berdasarkan hasil penilitian dan analisis dilapangan, maka Kesimpulan penelitian ini sebagai berikut; a). Ruang Publik yang dimanfaatkan Pedagang Kaki Lima yaitu pada area trotoar, depan halaman pertokoan dan pinggiran jalan raya menjadi sarana mereka untuk membuka lapak jualan. b). Dengan memanfaatkan setiap ruang publik yang di rasa strategis untuk membangun sebuah usaha dagangan mereka. c). keberadaan Pedagang Kaki Lima di Area ruang publik mempengaruhi arus lalu lintas di sepanjang 
lokasi tersebut menjadi terhambat karena menjadi areal parkir kendaraan sehingga mengurangi lebar jalan. Selain itu para pengguna trotoar; yaitu pejalan kaki menjadi terbatas ruang geraknya. e). Munculnya para penarik retribusi secara ilegal (pungutan liar), yang dibebankan kepada para Pedagang Kaki Lima serta kurangnya perhatian dan pengawasan dari pemerintah dari para pedagang sehingga membentuk ruang publik (areal jalan dan trotoar sebagai lapak jualan).

\section{DAFTAR PUSTAKA}

Arditama Erisandi .2016. Mengkaji Ruang Publik dari Perspektif Kuasa: Fenomena Kemenangan Aktor Hegemonik Melalui Dominasi Budaya. Jurnal Politik Copyright (C) 2021, the Authors. Published by Pendidikan Sosiologi Antropologi FKIP ULM 482 Indonesia volume 1 No. 1:69 (http://journal.unnes.ac.id, diakses 15 Desember 2018).

Creswell, John W. 20216. Research Design: Pendekatan Metode Kualitatif, Kuantitatif dan Campuran. Edisi Keempat (Cetakan Kesatu). Yogyakarta: Pustaka Belajar

Ritzer George \& goodman j douglas. 2017.

Teori Sosiologi dari Teori Sosiologi Klasik Sampai Perkembang Mutakhir Teori Sosial Postmodern. Kreasi Wacana: Perum Sidorejo Bumi Indah (SBI)
Rusdi, R., Kadir, M. A. A., Kelibey, I., \& Basri, L. (2021). Analisis Kinerja Satpol PP Dalam Penegakan PERDA Terhadap Pedagang Kaki Lima Di Kota Sorong. Journal Governance and Politics (JGP), 1(2), 10-24.

Ruswinarsih, M. F. S., \& Nur, R. (2021). Penggunaan Ruang Publik Sebagai Tempat Berjualan Pedagang Pasar Tungging Cempaka Raya Kelurahan Telaga Biru Kota Banjarmasin. PADARINGAN (Jurnal Pendidikan Sosiologi Antropologi), 3(3), 467482.

Sethuraman, S. V. 1991. Sektor Informal di Negara Sedang Berkembang. Urbanisasi, Pengangguran, dan Sektor Informal di Kota. C. Manning and T. N. Effendi: Jakarta,

Slamet Santoso. 2004. Dinamika Kelompok Sosial. Bumi Aksara: Jakarta.

Sumberlain:

Undang-Undang Nomor 26 Tahun 2007 tentang Penataan Ruang.

Peraturan Daerah Kota Sorong Nomor 36 Tahun 2013 Tentang Penataan dan Pembinaan Pedagang Kaki Lima.

\section{PROFIL SINGKAT}

Penulis, Uswatul Mardliyah,S.Sos.,M.Si lahir di Sorong,pada tanggal 23 Desember 1983. Pada jenjang pendidikan tinggi Penulis mengikuti studi pada S1 Jurusan Sosiologi (2004) Fakultas Ilmu Sosial Dan Ilmu Politik Universitas Al-Amin 
Muhammadiyah Sorong yang diselesaikan pada tahun 2008. Selanjutnya Penulis melanjutkan pendidikan S2 Pascasarjana Sosiologi di Universitas Pattimura Ambon, selesai pada tahun 2011. Aktifitas sekarang sebagai Dosen Tetap Prodi Sosiologi

Fakultas Ilmu Sosial dan Ilmu Politik Universitas Muhammadiyah Sorong. 